\title{
KEBIJAKAN HUKUM PIDANA MARITAL RAPE DALAM KONSEP PEMBAHARUAN HUKUM DI INDONESIA
}

\author{
Nurlaila Isima \\ Fakultas Syariah, Institut Agama Islam Negeri Manado, Indonesia \\ Email: nurlaila.isima@iain-manado.co.id
}

\begin{abstract}
ABSTRAK
Peraturan perundang-udangan dipertanyakan kemampuannya menyelesaikan marital rape di Indonesia, sehingga dalam tulisan ini membahas tentang proses kriminalisasi perkosaan dalam perkawinan, serta Pengaturan RUU Kekerasan Seksual tentang marital rape sebagai bentuk pembaharuan hukum pidana di Indonesia. Adapun tujuan yang ingin dicapai dari penulisan ini, yaitu untuk mengetahui bagaimana peraturan di Indonesia mengatur tentang marital rape sebagai perbuatan yang dilarang dan diancam sanksi pidana serta bagaimana marital rape dalam penal reform. Metode penelitian yang digunakan adalah penelitian hukum normatif, dengan menganalisis peraturan perundang-undangan dan rancangan undang-undang tentang perkosaan dalam perkawinan di Indonesia. Hasil dari penelitian ini adalah bahwa dalam KUHP tidak mengenal perkosaan dalam perkawinan, namun sejak diundangkannya UU PKDRT, perkosaan dalam perkawinan digolongkan dalam kekerasan seksual. UU PKDRT memudahkan istri sebagai korban untuk menjerat marital rape dengan tindak pidana kekerasan seksual. Dalam pembaharuan hukum pidana marital rape di Indonesia bisa dianalisis dalam RUU PKS dan RUU KUHP, di mana dalam kedua RUU tersebut menggolongkan perkosaan lebih luas dibandingkan dengan KUHP yang berlaku saat ini. Perkosaan tidak lagi dibatasi unsur "di luar perkawinan", akan tetapi perkosaan dalam perkawinan digolongkan dalam tindak pidana perkosaan.
\end{abstract}

Kata kunci: Marital Rape; Kekerasan Seksual; Perkosaan. 


\section{PENDAHULUAN}

Dewasa ini, kekerasan terhadap perempuan sekiranya merupakan suatu topik penting yang tidak pernah usai untuk dibahas, hal ini dikarenakan perempuan sering menjadi objek dari kekerasan itu sendiri, dimana dalam lingkungan sosial perempuan masih ditempatkan dan dianggap sebagai pihak yang lebih lemah daripada laki-laki. Kekerasan yang dialami oleh perempuan merupakan salah satu bentuk ketidakadilan gender yang biasa terjadi di masyarakat. Kekerasan yang dialami oleh perempuan bisa saja terjadi di mana saja. Dalam ruang lingkup keluarga; perempuan sebagai istri maupun anak, perempuan di tempat kerja, bahkan di tempat umum baik itu berupa pelecehan seksual, perkosaan, pembunuhan, penganiayaan, aborsi dan sebagainya.

Kekerasan terhadap perempuan merupakan tindakan yang merugikan perempuan baik secara fisik maupun non fisik. Kebanyakan orang memahami kekerasan hanya sebagai tindakan fisik yang kasar sehingga bentuk perilaku dalam bentuk kata-kata menyakitkan dan perilaku menekan tidak pernah diperhitungkan sebagai kekerasan. Padahal yang disebut kekerasan mencakup keseluruhannya. Salah satu contohnya kekerasan terhadap perempuan sebagai istri, hal ini dapat dilihat dari definisi tentang tindak kekerasan dalam rumah tangga sebagaimana disebutkan dalam BAB I ketentuan Umum pasal 1 UndangUndang-Undang Nomor 23 Tahun 2004 Tentang Penghapusan Kekerasan Dalam Rumah Tangga bahwa kekerasan dalam rumah tangga adalah setiap perbuatan terhadap seseorang terutama perempuan, yang berakibat timbulnya kesengasaraan ataupun penderitaan secara fisik, seksual, psikologis, dan/atau penelantaran rumah tangga termasuk ancaman untuk melakukan perbuatan, pemaksaan, atau perampasan kemerdekaan secara melawan hukum dalam lingkup rumah tangga.

Dalam Catahu (Catatan Tahunan) 2019 Komnas Perempuan menggambarkan beragam bentuk kekerasan terhadap perempuan yang terjadi sepanjang tahun 2018. Beberapa kasus yang perlu mendapat perhatian di antara lain 1) marital rape / perkosaan dalam perkawinan, 2) laporan inses (pelaku paling banyak adalah ayah dan paman), 3) kekerasan dalam pacaran yang dilaporkan ke instansi negara, dan 4) meningkatnya laporan pengaduan langsung ke Komnas Perempuan tentang kasus cyber crime berbasis gender.

Masih dalam Catahu Komnas Perempuan, Catatan Tahunan 2021 jumlah laporan terkait perkosaan terhadap istri adalah 100 kasus untuk 2020. Jika dibandingkan pada tahun 2019, data kasus mencapai 192 kasus yang dilaporkan. Artinya dari data ini tergambarkan grafik menaiknya kasus perkosaan terhadap istri (marital rape) di Indonesia. 
Dalam budaya patriarki, seorang perempuan memiliki posisi yang lebih inferior dibandingkan laki-laki sehingga membatasi ruang gerak dan berpikir bagi seorang perempuan. Superioritas dari laki-laki tersebut semakin kuat dalam ranah rumah tangga, di mana anggota keluarga wajib patuh terhadap laki-laki yang bertindak sebagai kepala keluarga sebagimana diatur dalam Undang-Undang Nomor 1 Tahun 1974 Tentang Perkawinan, tepatnya BAB IV Pasal 31 Ayat (3). Karena adanya berbagai diskriminasi dan kekerasan yang timbul akibat nilai-nilai dari budaya patriaki tersebut, maka timbulah perlawanan dari pihak yang paling dirugikan, yaitu dari para perempuan yang gerakannya disebut sebagai gerakan emansipasi ataupun feminisme.

Pemaksaan untuk berhubungan seksual yang dilakukan suami dianggap bukan suatu bentuk tindak pidana perkosaan. Hal inilah menjadi penyebab internal mendukung pandangan bahwa perkosaan hanya ada dalam unsur pidana "di luar perkawinan" oleh pelaku dalam hal ini adalah suami dan juga istri sebagai korban. Suami merasa bahwa perbuatan tersebut bukan merupakan suatu perbuatan yang salah menurut agama dan hukum, disamping itu korban juga beranggapan ada halhal yang membenarkan perbuatan pelaku. Hal ini diperkuat dengan kurang kesadaran diri dari korban bahwa didalam perkawinan pun, seorang istri memiliki hak asasi penuh atas tubuhnya. Ditambah dengan anggapan masyarakat pada umunya bahwa urusan rumah tangga tidak bisa intervensi dari luar karena merupakan urusan privat.

Berdasarkan pandangan yang berbeda tentang perkosaan dalam rumah tangga sehingga perlu dilakukan pengkajian mengenai bagaimana proses kriminalisasi tindak pidana perkosaan dalam perkawinan di Indonesia. Dalam sejarah hukum di Indonesia, Indonesia adalah negara yang mneganut sistem hukum Civil Law System yang dimana undang-undang merupakan sumber hukum pertama. Maka dalam tulisan ini, penulis akan melihat perjalanan panjang pengaturan marital rape dalam kebijakan penal di Indonesia serta marital rape dalam RUU PKS dan RUU KUHP sebagai bentuk pembaharuan hukum pidana.

\section{METODE PENELITIAN}

Penelitian bersifat deskriptif ini merupakan penelitian yuridis normatif, dengan menggunakan pendekatan undang-undang dan pendekatan konseptual. Penelitian ini menggunakan studi kepustakaan dengan mengumpulkan dan menganalisis bahan hukum primer, yaitu peraturan perundang-undangan, bahan hukum sekunder, yaitu buku-buku yang berkaitan dengan perkosaan, kekerasan seksual dalam rumah tangga dan hukum pidana. 


\section{HASIL DAN PEMBAHASAN}

\section{Pengertian Perkosaan dalam Perkawinan}

Menurut seorang kriminolog Mulyana W. K. sebagaimana dikutip oleh Wahid et al., (2001), bahwa terdapat 6 (enam) jenis perkosaan, yaitu:

a. Sadistic Rape. Dalam Sadistic Rape, pada perkosaan jenis ini pelaku mendapatkan kepuasan dengan cara melakukan serangan pada korban. Serangan diarahkan pada alat kelamin dan tubuh korban lainnya.

b. Angea Rape. Dalam jenis perkosaan ini, penganiyaan menjadikan tubuh korban sebagai obyek pelampiasan amarah.

c. Dononation Rape. Dalam hal ini perkosaan yang dilakukan kepada korban, karena pelaku menganggap bahwa pelaku lebih superior dibanding korban. Dengan kata lain pelaku memliki motif untuk menganiaya korban dan juga ingin memperkosa korban.

d. Seduktive Rape. Dalam perkosaan ini, terdapat adanya pemicu atau rangsangan. Ransangan bisa dari pelaku ataupun juga korban. Contohnya, rayuan dalam bentuk verbal. Mengakibatkan tanpa disadar pelaku memaksa korban untuk bersenggama tanpa ada penyesalan dan rasa bersalah.

e. Victim Precipitatied Rape. Pada jenis victim precipitatied rape lebih menekankan perbuatan perkosaan terjadi karena ulah korban sendiri. Maksudya korban sendiri yang mengakibatkan perkosaan itu terjadi.

f. Exploitation Rape. Pada jenis perkosaan ini pelaku memanfaatkan posisi yang ada padanya sebagai orang yang dibutuhkan dari segi ekonomi maupun status sosial yang ada pada diri pelaku. Sehingga pelaku dapat memanfaatkan korban karena kondisi dibutuhkan korban tersebut.

Berdasarkan penjelasan di atas, perkosaan dalam perkawinan dapat dikelompokan dalam jenis exploination rape. Kondisi ini dapat disimpulkan karena istri secara finansial dan sosial bergantung pada suami sebagai kepala rumah tangga dalam sebuah perkawinan. Suami memikul tugas memberikan nafkah kepada kelaurga. Sehingga dengan kondisi ini suami bisa memanfaatkan kekuasannya sebagai kepala rumah tangga untuk melakukan tindakan kejahatan kepada istri serperti memaksa istri untuk melakukan hubungan suami istri tanpa ada persetujuan dari korban.

Namun disisi lain menurut penulis dalam praktiknya banyak sekali kasus perkosaan dalam perkawinan bisa digolongkan dalam jenis sadistic rape. Dalam hal ini adalah suami ketika berhubungan badan memiliki kesenangan yang memberikan serangan pada istrinya misalnya dengan menyiksa, memukul, 
mencubit bahkan menyulut dengan rokok sebelum melakukan hubungan suami istri. Marital rape dapat diartikan sebagai salah satu jenis kekerasan dalam bentuk pemaksaan hubungan seksual oleh suami terhadap istrinya tanpa melihat keadaan atau kondisi istrinya.

Dilihat dari segi terminologi, marital rape adalah istilah Bahasa Inggris, terdiri dari kata marital dan rape. Marital adalah hal yang berkaitan dengan perkawinan, sedangkan rape artinya adalah perkosaan. Jadi marital rape dapat diartikan sebagai perkosaan yang dilakukan oleh suami dengan istri dalam hubungan perkawinan. Perkosaan dalam perkawinan (marital rape) dapat diartikan sebagai salah satu jenis kekerasan dalam bentuk pemaksaan hubungan seksual oleh suami terhadap istri tanpa mempertimbangkan kondisi atau keadaan istri (Ari \& Jaya, 2019). WHO mengelompokan perkosaan dalam perkawinan merupakan bagian dari bentuk sexual violence atau dikenal kekerasan seksual. Marital rape tidak hanya menyerang pada alat reproduksi korban akan tetapi mampu merusak keadaan fisik bahkan berdampak besar pada psikis korban dalam hal ini adalah istri (Siburian, 2020).

\section{Perkosaan dalam Perkawinan menurut KUHP}

Pengaturan marital rape tidak dapat ditemukan dalam KUHP. Perkosaan dalam KUHP hanya ada dalam 1 pasal yaitu Pasal 285 KUHP berbunyi: "Barang siapa dengan kekerasan atau ancaman kekerasan memaksa seorang wanita bersetubuh dengan dia di luar perkawinan, diancam karena melakukan pemerkosaan dengan pidana penjara paling lama dua belas tahun."

Dari pasal 285 KUHP, dapat dirumuskan unsur delik dalam pasal tersebut yaitu unsur "kekerasan atau ancaman kekerasan", unsur "memaksa bersetubuh" dan unsur "di luar perkawinan". Perkosaan hanya dikategorikan jika memaksakan hubungan seksual dengan Wanita yang bukan istrinya artinya pelaku dan korban tidak terikat pernikahan (Marlia, 2007).

Selama ini unsur di luar perkawinan yang tertuang dalam Pasal 285 KUHP sah-sah saja di Indonesia. Karena adanya pandangan bahwa tidak mungkin dalam sebuah pernikahan akan terjadi perkosaan. Karena pada hakikanya kewajiban seorang istri untuk melayani suaminya. Di samping itu, secara agama dan sosial istri memiliki kewajiban untuk tunduk dan taat pada suaminya. Hal ini merupakan sebuah budaya patriarki. Di mana suami dianggap orang kuat dari segi fisik. Di samping itu, seorang istri ada di bawah suami dalam rumah tangga sehingga hal inilah yang mebatasi seorang istri untuk bergerak. 
Hal ini mengakibatkan di Indonesia, jika ada unsur paksaan suami dalam menuntut pelayanan berhubungan dengan urusan hubungan seksual dari seorang istri tidak dapat dikategorikan sebagai tindak pidana perkosaan. Kondisi inilah bisa dikatakan menjadi variabel pendukung bahwa perkosaan hanya bisa dikategorikan pada perkosaan dengan unsur "di luar perkawinan". Jadi secara tidak langsung baik korban maupun pelaku beranggapan bahwa paksaan yang dilakukan dalam hubungan seksual suami kepada istri bukan merupakan tindak pidana perkosaan. Ditambah kurang pemahaman istri bahwa meskipun sudah berumahtangga istri masih memiliki hak atas dirinya sendiri. Memiliki kesempatan dan kemampuan untuk mengurus dan mandiri atas tubuhnya sendiri.

Dari penjelasan di atas, bahwa Pasal 285 KUHP tidak mampu menanggulangi tindak pidana perkosaan dalam perkawinan dan tidak bisa dijadikan sebagai dasar untuk menghukum pelaku. Pada praktiknya, marital rape hanya dapat didasarkan pada pasal penganiayaan yaitu Pasal 351 dan 353 KUHP. Sedang kita tahu bersama bahwa pasal ini masih sangat jauh memberikan perlindungan pada korban dan untuk menjerat pelaku karena terlalu umum dan dari sanksi pidana yang masih tergolong ringan jika dibandingkan dengan akibat dan dampak yang dirasakan oleh korban akibat perkosaan dalam perkawinan tersebut. Sehingga dapat disimpulkan bahwa tindak pidana perkosaan dalam KUHP mengatur terlalu sempit.

\section{Perkosaan dalam Perkawinan (Marital Rape) menurut UU PKDRT}

Selaras dengan ground norm Indonesia yaitu Pancasila dan juga UUD Tahun 1945, bahwa setiap warga negara harus mendapatkan rasa aman dari segala bentuk kekerasan. Kekerasan di sini juga termasuk kekerasan dari lingkup domestik rumah tangga. Kekerasan dalam rumah tangga juga merupakan bentuk diskriminasi dan pelanggaran terhadap martabat korban sehingga harus bisa diselesaikan. Mengingat hal ini, maka disahkannya UU PKDRT pada tahun 2004. UU PKDRT menjadi salah satu usaha pemerintah untuk menegakan segala jenis kekerasan dalam rumah tangga di Indonesia. Selain itu merupakan upaya dalam pemberantasan kekerasan dalam rumah tangga yang dulu dianggap sesuatu yang tabu untuk dibahas, dicegah dan diberantas. Kekerasan dalam rumah tangga merupakan sesuatu yang fakta terjadi di masyarakat, dalam hal ini juga perkosaan dalam rumah tangga.

Kehadiran UU PKDRT membuka jalan bagi terungkapnya kasus kekerasan dalam rumah tangga dan upaya perlindungan hak-hak korban. Pada awalnya kekerasan dalam rumah tangga dianggap merupakan wilayah privat yang tidak seorangpun di luar lingkungan rumah tangga dapat memasuki ranah tersebut. Dalam perjalanannya UU ini masih ada beberapa pasal yang tidak 
menguntungkan bagi perempuan korban kekerasan. PP No. 4 Tahun 2006 tentang Pemulihan merupakan peraturan pelaksana dari UU sebagaimana yang tertera dalam mandat UU ini (Hadikusuma, 2020). Menurut Pasal 1 UU PKDRT yang berbunyi:

"Segala bentuk kekerasan dalam rumah tangga merupakan perbuatan melawan hukum. Sesuai dengan tujuan dari undang-undang ini yang ingin mencegah segala bentuk kekerasan dalam rumah tangga, melindungi korban kekerasan dalam rumah tangga, menindak pelaku kekerasan dalam rumah tangga, dan memelihara keutuhan rumah tangga yang harmonis dan sejahtera"

Pasal 1 di atas dapat disimpulkan bahwa keberadaan UU PKDRT adalah undang-undang pertama yang mengkriminalisasi perkosaan dalam perkawinan. Selanjutnya marital rape diatur secara tegas dalam pasal 5, 8 dan 46 UU PKDRT. Kemudian dalam Pasal 5 UU PKDRT mengatur bahwa:

"Setiap orang dilarang melakukan kekerasan dalam rumah tangga terhadap orang dalam lingkup rumah tangganya, dengan cara: kekerasan fisik, kekerasan psikis, kekerasan seksual atau penelantaran rumah tangga”.

Pasal 5 salah satu jenis kekerasan dalam rumah tangga diakomodir dalam UU PKDRT adalah kekerasan seksual. Selanjutnya kekerasan seksual diatur lebih rinci dalam pasal 8 UU PKDRT. Pasal 8 mengatur kekerasan seksual, yaitu: Pertama, pemaksaan hubungan seksual yang dilakukan terhadap orang yang menetap dalam lingkup rumah tangga tersebut; dan Kedua, pemaksaan hubungan seksual terhadap salah seorang dalam lingkup rumah tangganya dengan orang lain untuk tujuan komersial dan/atau tujuan tertentu.

Jika merujuk pada penjelasan pasal 8 , bahwa bentuk pemaksaan hubungan seksual, pemaksaan dengan cara tidak wajar dan/atau tidak disukai, pemaksaan hubungan seksual dengan orang lain untuk bertujuan komersial dan/atau tujuan tertentu adalah bagian dak kekerasan seksual. Sedangkan untuk sanksi pidana yang bisa mengancam pelaku kekerasan seksual berupa pemaksaan hubungan seksual adalah jenis sanksi pokok berupa pidana penjara atau pidana denda. Hal ini ditemukan dalam pasal 46 UU PKDRT menegaskan atas perbuatan tersebut diancam dengan pidana penjara paling lama 12 tahun atau denda paling banyak Rp. 36.000.000.

Mengingat bahwa subyek dalam UU PKDRT bukan hanya suami istri, sehingga memang tidak secara ekskusif perkosaan dalam perkwaninan sebagai kekerasan seksual. Karena perlu diingat bahwa keberadaan UU PKDRT adalah 
bentuk upaya untuk menghapus segala kekerasan yang mungkin terjadi dalam rumah tangga,, sehingga memberikan jaminan perlindungan bagi korban kekerasan. Dengan kata lain UU ini merupakan bentuk kekhusussam bagi penegakan hukum terhadap kekerasan terutama perkosaan dalam perkawinan.

Menurut penulis, keberadaan UU PKDRT sangat membantu korban KDRT dalam hal ini adalah istri tergolong sulit memperoleh keadilan. Hal ini dikarena sebelum adanya UU PKDRT Indonesia belum memiliki peraturan tentang marital rape untuk menjamin keadilan korban dan kepastian hukum bagi penegak hukum untuk menghukum pelaku kekerasan seksual suami terhadap istri. Selain itu, keberadaan UU PKDRT pula mampu perlahan menggeser pandangan masyarakat, bahkwa kekerasan dalam rumahtangga bukan lagi masalah domestik dalam ranah privat, akan tetapi masyarakat juga harus menyadari bahwa perlunya intervensi pihak luar dalam memberikan keadilan bagi korban kekerasan dalam rumah tangga pada umunya dan perkosaan dalam perkawinan pada khususnya berkaitan dengan urusan suami istri (Soeroso, 2010).

\section{Perkosaan dalam Perkawinan menurut Hukum Islam}

Larangan melakukan pemaksaan hubungan seksual ini berlaku juga bagi pasangan suami istri. Suami tidak bisa memaksakan keinginannya untuk berhubungan seksual dengan istrinya, apabila istrinya tersebut melakukan penolakan, begitupun sebaliknya. Termasuk juga dalam kategori kekerasan seksual dalam pengertian pemaksaan hubungan seksual, yaitu pemaksaan cara atau gaya berhubungan dengan tidak wajar atau tidak disukai oleh salah satu pihak, suami atau istri.

Pemaksaan hubungan seksual pada dasarnya tidak sejalan dengan kebiasaan masyarakat yang baik. Perbuatan ini tidak sesuai dengan hati nurani manusia. Telah banyak peraturan-peraturan yang dibuat untuk menghapus perilaku buruk terhadap perempuan. Undang-Undang No. 23 Tahun 2004 Tentang Penghapusan Kekerasan Dalam Rumah Tangga (PKDRT) adalah salah satu bentuk usaha pemerintah untuk menghilangkan kekerasan dalam keluarga yang sebagian besar korbannya adalah wanita.

Dalam Hukum Islam seorang istri tidak boleh menolak apabila suami menginginkan hubungan intim, sebagaimana bunyi hadis dari Abu Hurairah yang berbunyi: "Apabila seorang laki-laki mengajak istrinya ke ranjangnya, lalu istri tidak mendatanginya, hingga dia (suaminya) bermalam dalam keadaan marah kepadanya, maka malaikat melaknatnya hingga pagi tiba." (HR. Bukhari dan Muslim). 
Hadits di atas menunjukkan wajibnya seorang wanita memenuhi keinginan suami dalam masalah jima', sekalipun sang istri dalam keadaan sibuk dengan urusan rumah yang penting, tidak boleh meninggalkan suami atau bersikap masa bodoh terhadapnya. Selama ini kekerasa suami terhadap istri dalam pemaksaan hubungan seksual jarang mendapat perhatian masyarakat. Suami yang memaksakan hubungan senggam jarang dimunculkan oleh istrinya. Lemahnya kedudukan istri dalam masyarakat dan keluarga menjadi salah satu penyebabnya serta bagi istri sendiri hal itu merupakan aib bagi keluarganya.

Lebih lebih peran publik yang berasumsi laki-laki punya hak otonom dalam keluarganya membuat laki-laki berhak melakukan apa saja terhadap perempuannya, dan kebanyakan laki-laki menganggap bahwa perkawinan merupakan legimitasi resmi kekuasaan terhadap perempuan.

\section{Perkosaan dalam Perkawinan pada Pembaharuan Hukum Pidana (Penal Reform)}

Lain halnya dengan KUHP sebagaimana dalam Pasal 285 KUHP yang mengandung unsur "di luar perkawinan", unsur kekerasan atau ancaman kekerasan dalam tindak pidana menurut pasal tersebut yakni memaksa perempuan yang bukan istrinya artinya d(tidak terikat dalam perkawinan) dengan pelaku untuk melakukan hubungan seksual maka dari itu pemaksaan hubungan seksual yang terjadi dalam hubungan yang terikat dengan perkawinan tidak dapat dikatakan sebagai tindak pidana.

Jika menelaah naskah akademik RUU PKS (Rancangan Undang Undang Penghapusan Kekerasan Seksual), bahwa perkosaan juga bisa dalam rumah tangga. Pihak yang paling rentan dalam marital rape adalah perempuan yaitu istri. Menurut sebagian orang dan masyarakat masih menganggap bahwa dalam praktik marital rape terhadap istri itu tidak pernah ada. Namun pada faktanya banyak sekali laporan yang dilakukan oleh para istri kepada pihak kepolisian dan pihak yang terkait bahwa korban istri sering mengalami pemakasaan oleh suami yang bisa mengakibatkan kekerasan fisik dan memungkinkan menggangu kesehatan reproduksi perempuan.

Pemberantasan dan pencegahan tindak pidana kekerasan seksual kini termuat dalam RUU PKS menerjemahkan kekerasan seksual tidak sesempit UU PKDRT. Kekerasan seksual dalam RUU PKS lebih luas dan lebih banyak jenisnya. Sebagaimana tertuang dalam pasal 11 RUU PKS berbunyi :

1) Setiap orang dilarang melakukan Kekerasan Seksual.

2) Kekerasan seksual terdiri dari: 

a. pelecehan seksual;
b. eksploitasi seksual;
c. pemaksaan kontrasepsi;
d. pemaksaan aborsi;
e. perkosaan;
f. pemaksaan perkawinan;
g. pemaksaan pelacuran;
h. perbudakan seksual, dan/atau;
i. penyiksaan seksual.

3) Kekerasan seksual sebagaimana dimaksud pada ayat (1) meliputi peristiwa kekerasan seksual dalam lingkup relasi personal, rumah tangga, relasi kerja, publik, dan situasi khusus lainnya."

Selanjutnya dalam Pasal 16 menerangkan bahwa perkosaan dalam Pasal 11 ayat 2 yang dilakukan dengan kekerasan, ancaman kekerasan, tipu muslihat, menggunakan kondisi seseorang yang tidak mampu memeberikan peretujuan untuk melakukan hubungan seksual merupakan kekerasan seksual.

Isu marital rape dan kekerasan seksual secara umum, terdapat perbedaan pembahasan dalam UU PKDRT dan RUU PKS antara lain sebagai berikut:

1. Dalam RUU PKS membahas lebih luas mengenai jenis kekerasann seksual, salah satunya keberadaan tentang marital rape. Namun pembahasan ini belum disahkan oleh negara saat ini. Kedua, mengenai subjek yang menjadi korban dalam kekerasan seksual. RUU PKS membahas secara luas bahwa relasi khusus pelaku dengan korban itu tidak hanya berpatokan dalam ranah hubungan suami istri saja.

2. Dalam UU PKDRT, marital rape diancam dengan jenis pidana pokok berupa pidana penjara paling lama 15 tahun atau denda. Dibandingkan dengan RUU PKS kekerasan seksual dalam pasal 11 diancam dengan pidana berbentuk minimum khusus dengan ancaman maksimal dan minimal sesuai diterangkan dalam pasal 108 - 115 RUU PKS, dengan pidana penjara dan ganti kerugian, kerja social pembinaan khusus serta pencabutan hak asuh sebagai bentuk pidana tambahan atas tindak pidana tersebut.

3. Perbedaan berikut pada delik berkualifikasi dalam hukum pidana terhadap perkosaan. Dalam kondisi tertentu terdapat hal-hal yang dapat memberatkan pelaku terhadap penjara yang dipidanakan. Contohnya, terhadap perbuatan pelaku dapat menghilangkan nyawa seseorang maksimal pidana yang dapat diberikan kepada pelaku adalah 20 tahun 
pidana penjara. Hal ini tidak dikenal dalam UU PKDRT, dalam aturannya tidak adanyanya kualifikasi khusus untuk kekerasan seksual. Hal ini dikarenakan kualifikasi di lura tetang perbuatan pidana terdapat mengenai kekerasan seksual.

4. RUU PKS tidak hanya menekankan pada upaya reprensi dalam pencantuman hukum pidana namun juga menekankan pada $\mathrm{u}$ paya preventive juga. RUU PKS menngatur bahwa upaya represif kekerasan seksual harus termuat dalam aturan yang dikeluarkan oleh negara, pemerintah, hingga di level daerah, serta keikutsertaan masyarakat mengenai penguatan kapasitas terkait pemberantasan dan pencegahan kekerasan seksual melalui lembaga atau kelompok masyarakat, keagamaan, kepercayaan dan adat. Sedangkan dalam UU-PKDRT tidak mencatumkan upaya pencegahan kekerasan seksual.

Dengan demikian lembaga legislatif yang memiliki kekuasaan untuk membentuk undang-undang, maka haru dipastikan bahwa undang-undang yang dibuat sesuai dengan keinginan dan pemikiran masyarakat. Karena kesalahan pembentukan undang-undang yang dibuat oleh pemerintah akan berdampak langsung kepada masyarakat serta aturan-aturan yang berada dibawahnya.

Dibandingan dengan RUU PKS, di dalam RUU KUHP marital rape tergolong dalam tindak pidana kesusilaan yang kategorinya terkait persolaan seksualitas. Hal ini terlihat dalam beberapa pengaturan dalam Bab Kesusilaan dalam RUU KUHP. Dalam RUU KUHP terdapat delik yang berhubungan hak wanita berkaitan dengan hak reproduksi dan masalah seksual. Misalahnya tindak pidana dimuka umum, pronografi, permufakatan jahat, zina dan perbuatan cabul, dan pengobatan yang menyebabkan terjadinya keguguran kandungan.

Pasal tersebut mengatur tentang delik perkosaan, perbuatan cabul, inses, serta perdagangan manusia khusus perempuan dan anak untuk eksploitasi seksual. Artinya delik-delik di atas merupakan tindak pidana menyerang tubuh manusia yang hubungan dengan masalah seksual (Lumingkewas, 2016).

Menurut RUU KUHP, marital rape dikatogerikan mirip dengan kasus perkosaan. Hal ini dikarenakan marital rape dalam RUU KUHP dianggap bagian dari delik perkosaan yang terjadi dalam rumah tangga. Dapat dikatakan jika suatu Tindakan yanga mengandung unsur seksual dan didalamnya terdapat "pemaksaan atau melakukan hubungan seksual tanpa persetujuan wanita" maka dikategorikan dalam delik pemerkosaan. Dalam hal ini yang dapat membedakan hanya pada pemaknaan delik perkosaan dengan unsur "diluar perkawinan" dengan unsur "di dalam perkawinan". 
Hal yang membedakan KUHP yang berlaku saat ini dengan konsep dalam Rancangan KUHP. Dalam pembahasan perkosaan, di mana menambahkan pembahasan marital rape yang sebelumnya dalam KUHP tidak tergolong dalam pasal perkosaan karena terbatas pada unsur "di luar perkawinan". Ini membuktikan bahwa adanya perluasaan bahasan dan fokus kajian dalam hukum positif di Indonesia terkait perkosaan dalam perkawinan.

Dalam Rancangan KUHP terdapat pasal-pasal yang menitikberatkan dan menjatuhkan pemidanaan bagi pelaku perkosaan dalam perkawinan. Hal ini tertuang dalam Rancangan KUHP yang mengatur tentang aturan-aturan hukum yang membahas tetang perkosaan dalam perkawinan sebagaimana dituangkan dala pasal 480 ayat 1 dan 2 poin a Rancangan KUHP yang berbunyi.

“1) Setiap orang yang dengan Kekerasan atau Ancaman Kekerasan memaksa sesorang bersetubuh dengannya dipidana karena melakukan perkosaan, dengan pidana penjara paling lama 12 (dua belas) tahun. 2) Termasuk tindak pidana perkosaan dan dipidana sebagaimana dimaksud pada ayat (1) meliputi perbuatan: a) Persetubuhan dengan sesorang dengan persetujuannya, karena orang tersebut percaya bahwa orang itu merupakan suami/istrinya yang sah (Irham et al., 2021).”

Berdasarkan pasal tersebut jelas menggambarkan bahwa suatu Tindakan dapat dikualifikasi sebagai perkosaan dalam perkawinan jikalau suatu tindakan tersebut berisi unsur "perkosaan" terdapat unsur "pemaksaan" atau Tindakan mengikuti kemauan pelaku untuk berhubungan seksual suami istri. Pasal tersebut pula RUU KUHP, menandakan adanya perluasan dalam menetukan kategori perkosaan dibandingkan dalam KUHP yang berlaku saat ini. Meskipun pasal ini dimaknai secara garis besar, akan tetapi apabila dimaknai secara khusus, dalam sebuah hubungan pernikahan kaitannya yang melakukan adalah pelaku dan istrinya maka dapat dikualifikasi dalam suatu delik "perkosaan".

Walaupun pasal tersebut menafsirkan secara umum, namun jika ditafsirkan secara khusus dalam suatu ikatan perkawinan dalam hal ini yang melakukan itu adalah suami terhadap istrinya maka dapat dikategorikan sebagai suatu tindak pidana perkosaan. Dengan pasal tersebut, jika suami melakukan tindak pencabulan kepada istrinya sesuai dengan pasal 480 ayat (3) RUU KUHP maka perbuatan suami dapat dikategorikan sebagai tindakan perkosaan.

Tindakan cabul dalam pasal 480 ayat (3) RUU KUHP berbunyi: "Dianggap juga melakukan tindak pidana perkosaan, jika dalam keadaan sebagaimana dimaksud pada ayat (1) dan ayat (2) dilakukan perbuatan cabul berupa: a. Memasukkan alat kelamin ke dalam anus atau mulut orang lain; b. 
Memasukkan alat kelamin orang lain kedalam anus atau mulutnya sendiri; atau c. Memasukkan bagian tubuhnya yang bukan alat kelamin atau suatu benda kedalam alat kelamin atau anus orang lain.

\section{KESIMPULAN}

Sebelum diundangkannya UU PKDRT, para korban KDRT sulit untuk mendapatkan keadilan, serta pelindungan hukum, hal ini diakibatkan karena belum adanya payung hukum yang tegas, serta paradigma bahwa tidak ada intervensi pihak dalam masalah rumah tangga, karena dianggap sebagai masalah privat suami istri. Hal ini tercermin dalam pasal 285 KUHP yang mengandung unsur "di luar perkawinan". Dapat dikatakan bahwa UU PKDRT menjadi pembuka jalan bagi korban perkosaan dalam perkawinan untuk mencari keadilan. Dalam pembaharuan hukum pidana, baik ditinjau dalam RUU PKS dan RUU KUHP, marital rape mendapatkan porsi khusus. Hal ini bisa tercermin dalam kedua RUU tersebut bahwa marital rape ditentukan sebagai salah satu bentuk perkosaan. Dalam arti, adanya perluasan makna perkosaan yang sebelumnya adanya unsur "di luar perkawinan", sehingga marital rape tidak tergolong dalam perkosaan. Akan tetapi, dalam kedua RUU tersebut aturan perkosaan dalam perkawinan bisa dipidana.

\section{REFERENSI}

Ari, N. M. S. A., \& Jaya, I. B. S. D. (2019). Perkosaan Dalam Perkawinan (Marital Rape) Ditinjau Dari Undang-Undang Penghapusan Kekerasan Dalam Rumah Tangga. OJS Hukum UNUD, 8(7), 1-14.

Hadikusuma, H. (2020). Hukum Perkawinan Indonesia: Menurut Perundangan, Hukum Adat, Hukum Agama. CV. Mandar maju.

Irham, M., Thahir, H., \& Istiqamah, I. (2021). Tinjuan Hukum Islam Tentang Marital Rape Dalam Rumah Tangga Terkait Rancangan Undang-Undang Hukum Pidana. Qadauna: Jurnal Ilmiah Mahasiswa Hukum Keluarga Islam, 3(1), 131-145.

Lumingkewas, F. (2016). Tindak Pidana Kesusilaan Dalam KUHP dan RUU KUHP serta Persoalan Keberpihakan Terhadap Perempuan. Lex Crimen, $5(1)$.

Marlia, M. (2007). Marital Rape; Kekerasan Seksual terhadap Istri. Pustaka Pesantren. 
Al-Mujtahid: Journal of Islamic Family Law Vol. 1, No. 2 (2021): 125-138

Website: http://journal.iain-manado.ac.id/index.php/almujtahid

Siburian, R. J. (2020). Marital Rape Sebagai Tindak Pidana dalam RUUPenghapusan Kekerasan Seksual. Jurnal Yuridis Vol, 7(1), 149-169.

Soeroso, M. H. (2010). Kekerasan Dalam Rumah Tangga dalam Perspektif Yuridis-Viktimologis. Sinar Grafika.

Undang-Undang Nomor 1 Tahun 1974 tentang Perkawinan, (1974).

Undang-Undang Nomor 23 Tahun 2004 tentang Penghapusan Kekerasan dalam Rumah Tangga, (2004).

Wahid, A., Irfan, M., \& Hasan, M. T. (2001). Perlindungan Terhadap Korban Kekerasan Seksual Advokasi atas Hak Asasi Perempuan. Refika Aditama. 